ORIGINAL ARTICLE

\title{
$\alpha$-B-Crystallin as a Tissue Marker of Epileptic Foci in Paediatric Resections
}

\author{
Harvey B. Sarnat, Laura Flores-Sarnat
}

\begin{abstract}
Background: We studied $\alpha$-B-crystallin, a small heat shock chaperone protein upregulated by various "stresses", as an immunocytochemical tissue marker of epileptic foci. Methods: We examined 45 resected brain tissues of epileptic patients, 16 months to 23 years. Postmortem brains of 2 epileptic children and 20 normal fetuses and neonates of 10-41 weeks gestation similarly were studied. Immunocytochemical demonstration of $\alpha$-B-crystallin was supplemented by neuronal, glial and inflammatory cell markers and electron microscopy (EM) in surgical cases. Autopsy brain tissue of children without epilepsy or neurological disease served as controls. Results: In all resections, $\alpha$-B-crystallin was overexpressed in astrocytes and oligodendrocytes, including satellite cells adherent to neurons, and occasionally in neurons of neocortex, hippocampus and amygdala. In six cases, reactivity was most intense at or near the epileptic focus, with a diminishing gradient of intensity for $2-3 \mathrm{~cm}$; similar focal expression was seen in autopsy cases. Presence or absence of histological structural lesions was independent of $\alpha$-B-crystallin expression. Balloon cells and giant atypical cells in tuberous sclerosis were intensely reactive. Reactivity was present in DNETs. No correlation occurred with microglial activation, inflammation or gliosis; no ultrastructural alterations were seen. No expression was seen in fetal brains at any age. Conclusions: Immunoreactive $\alpha$ $\mathrm{B}$-crystallin is a reliable tissue marker of epileptic foci, regardless of presence or absence of structural lesions; at times it maps the extent of a focus.
\end{abstract}

RÉSUMÉ: L' $\alpha$-B-crystalline comme marqueur des tissues des zones épileptogènes chez l'enfant. Introduction: Nous avons étudié une petite protéine chaperon nommée $\alpha$-B-crystalline comme marqueur immunocytochimique des tissus des zones épileptogènes. Cette protéine est surexprimée par différents stresseurs. Méthode: Nous avons examiné les tissus cérébraux provenant de résections chirurgicales de 45 patients épileptiques agés de 16 mois à 23 ans. Aussi, nous avons étudié de la même manière les cerveaux provenant de l'autopsie de 2 enfants épileptiques et de 20 foetus ou nouveaux-nés normaux de 10 à 41 semaines de gestation. La démonstration immunocytochimique de l' $\alpha$-B-crystalline s'accompagne de marqueurs cellulaires pour les neurones, les cellules gliales et les cellules inflammatoires en plus de la microscopie électronique pour les spécimens chirurgicaux. Les tissus cérébraux provenant d'enfants sans atteinte neurologique servent à titre de contrôle. Résultat : Pour toutes les résections, l' $\alpha$-B-crystalline est sureprimée dans les astrocytes et les oligodendrocytes, incluant les cellules satellites s'adhérant parfois aux neurones. On la retrouve parfois aussi dans les neurones du néocortex, de l'hippocampe et de l'amygdale. Dans 6 cas, la réactivité était plus intense au sein ou près de la zone épileptogène, avec un gradient de réactivité décroissant sur 2 à $3 \mathrm{~cm}$. Cette expression focalisée n'est pas observée dans les cas d'autopsie. La présence ou absence de lésions structurales est indépendente de l'expression de l' $\alpha$-B-crystalline. Les cellules ballonnisées et cellules géantes observées dans les cas de Sclérose Tubéreuse ont une réactivité intense. La réactivité est aussi présente dans les tumeurs dysembryoplasiques neuroépithéliales (DNT). Il n'existe pas de correlation avec l'activation des microglies ou des cellules inflammatoires pas plus qu'avec la gliose. Il n'y a pas d'altération ultrastructurale évidente. Toute expression est absente dans les cerveaux foetaux. Conclusion : L'immunoréactivité de l' $\alpha$-B-crystalline est un marqueur fiable des zones épileptiques indépendamment de la présence de lésions structurales. Parfois, elle délimite la zone épileptogène.

Can. J. Neurol. Sci. 2009; 36: 566-574

The precise localization of epileptic foci by electroencephalographic (EEG) telemetry and neuroimaging, and by intraoperative electocorticography $(\mathrm{ECoG})$ is primordial in the success of surgical treatment of epilepsy by resection. Neuropathological examination to determine the presence and nature of lesions does not define anatomical limits of an epileptic focus. Seizures may arise in "normal" tissue adjacent to lesions or there may be no microscopic lesions. It would be useful for prognosis and patient management to determine whether resection of an epileptic focus is complete, analogous to the margins in tumour resections. None of the routine neuronal and glial markers distinguishes epileptic from nonepileptic cerebral tissue. Such neuropathological information could better define completeness of resection of epileptic foci and provide another predictor of outcome ${ }^{1-3}$.
To address this problem, we studied a series of potential markers. After inconclusive evidence using histochemical stains of mitochondrial oxidative enzymes with frozen sections of resected brain tissue, we decided to try a heat shock protein (HSP) because this group of molecules is upregulated in a variety of stresses to tissue. We chose $\alpha$-B-crystallin because this small HSP has anti-apoptotic and neuroprotective functions

\footnotetext{
From the Departments of Paediatrics, Pathology (Neuropathology) and Clinical Neurosciences, Alberta Children's Hospital and University of Calgary Faculty of Medicine, Calgary, Alberta, Canada.

Received February 23, 2009. Final Revisions Submitted April 8, 2009 Correspondence to: Harvey B. Sarnat, Alberta Children's Hospital, 2888 Shaganappi Trail NW, Calgary, Alberta, T3B 6A8, Canada.

Email: harvey.sarnat@albertahealthservices.ca
} 
and is strongly expressed in brain tissue in ischaemia and other physiologically stressful conditions, and also because of our familiarity with this antibody from studies in nonepileptic conditions. The human genome encodes ten $\alpha$-B-crystallinrelated small heat shock proteins that include HSP- $27^{4}$, the HSP most closely related structurally to $\alpha$-B-crystallin. The $\alpha$-Bcrystallin molecule derives its name from a sister molecular chaperone, $\alpha$-A-crystallin, strongly expressed in lens placode of the developing eye $\mathrm{e}^{5,6}$. The upregulation of $\alpha$-B-crystallin in neurons and glial cells is well documented in some neurodegenerative diseases and neuromuscular disorders, but has been little studied as a "stress" in human epilepsy, though demonstrated in rodents? .

\section{Materials And Methods}

Subjects (Surgical cases). During a four-year period from July 2005 to January 2009, 45 surgical resections of epileptic foci were performed at Alberta Children's Hospital (four cases at Foothills Hospital, also in Calgary) in patients ranging from 16 months to 18 years of age. Of these 43 cases, 8 were 3 years of age or less; 19 were $4-12$ years, 18 were adolescents and a young woman age 23 years. Gender ratio was equal: 22 females and 23 males. Neoplasms of the brain were excluded. Dysembryoplastic neuroepithelial tumour (DNET) was regarded as primarily a developmental malformation and five cases were included. None of our patients had hydrocephalus. None had cerebral edema.

Clinical studies. All patients underwent preoperative EEG telemetry, including subdural grids and intraoperative ECoG. Epileptic foci in resected tissue were determined by these localizations. Patients also underwent magnetic resonance imaging (MRI) pre- and post-operatively. Computed tomogram of the brain also was performed in some cases, and all subjects underwent extensive neuro-psychological and neurological evaluation. The cases are summarized in the Table.

Tissue preparation. In some cases, the hippocampus and/or amygdala was resected en bloc. Blocks of neocortex varied in size, but measured an average of $4 \mathrm{~cm} \times 2 \mathrm{~cm}$ and included subcortical white matter. Tissue was received in the laboratory within minutes after resection and processed immediately. The routine period of fixation in $10 \%$ buffered formalin was $12-18$ hours for all surgical tissues. Sections of the fresh or formalinfixed specimens were made perpendicular to the long axis of the gyrus and four to six blocks were taken in sequence, including the margins. In the centre of the block was an epileptic focus identified electrophysiologically; the neurosurgeon removed equal amounts of tissue on either side, unless one end encroached upon an "eloquent" area that would risk neurological deficits if resected, but this was rarely a factor. The distance of each tissue section from the centre (the epileptic focus) was then estimated within a $2-3 \mathrm{~mm}$ error.

Tissues were studied with antibodies against $\alpha$-B-crystallin (Covance: Emeryville, California, USA; polyclonal LAP-70 carboxy-terminus antibody against peptide of the last 14 amino acids; host: rabbit; 1:50 dilution incubated at $37^{\circ} \mathrm{C}$ ). A battery of other immunocytochemical and histochemical neuronal and glial markers also was applied: neuronal nuclear antigen (NeuN); synaptophysin; vimentin; glial fibrillary acidic protein, polyclonal antibody (GFAP); CD-43 T-lymphocyte and macrophage marker; CD-68 microglial and macrophage marker;
Table: Surgical resections of epileptic foci: ages, gender, site in brain and histopathological diagnoses

\begin{tabular}{|c|c|c|c|}
\hline Case & $\begin{array}{c}\text { Age/ } \\
\text { Gender }\end{array}$ & Site & Diagnosis \\
\hline 1 & $8 y r / F$ & L temp-occip & focal cortical dysgenesis \\
\hline 2 & $14 \mathrm{yr} / \mathrm{M}$ & L temporal & focal cortical dysgenesis \\
\hline 3 & $7 y r / F$ & L temp-par-occ & $\begin{array}{l}\text { focal cortical dysgenesis; } \\
\text { neuronal }\end{array}$ \\
\hline & & L hippocampus & loss CA1,CA3 \\
\hline 4 & $13 y r / F$ & R temporal & $\begin{array}{l}\text { viral encephalitis; partial status } \\
\text { epilepticus }\end{array}$ \\
\hline 5 & $15 \mathrm{yr} / \mathrm{F}$ & R temporal & tuberous sclerosis \\
\hline 6 & $16 \mathrm{mo} / \mathrm{M}$ & $\begin{array}{l}\text { R temporal; } \\
\text { R hippo,amyg }\end{array}$ & $\begin{array}{l}\text { no neocortical lesions } \\
\text { mesial gliosis }\end{array}$ \\
\hline 7 & $6 y r / M$ & $\begin{array}{l}\text { L temporal; } \\
\text { L hippo,amyg }\end{array}$ & $\begin{array}{l}\text { cortical and subpial gliosis } \\
\text { mesial gliosis }\end{array}$ \\
\hline 8 & $7 \mathrm{yr} / \mathrm{F}$ & $\mathrm{R}$ frontal & tuberous sclerosis \\
\hline 9 & 3yr/F & $\begin{array}{l}\mathrm{R} \text { temporal; } \\
\mathrm{R} \text { hippocampus }\end{array}$ & $\begin{array}{l}\text { focal cortical dysgenesis } \\
\text { mesial gliosis }\end{array}$ \\
\hline 10 & $18 y r / F$ & $\begin{array}{l}\mathrm{R} \text { temporal; } \\
\mathrm{R} \text { hippocampus }\end{array}$ & $\begin{array}{l}\text { no neocortical lesions; } \\
\text { neuronal loss CA2 }\end{array}$ \\
\hline 11 & 15yr/M & $\mathrm{R}$ frontal & gliosis \\
\hline 12 & 13yr/M & R hippocampus & DNET \\
\hline 13 & $10 \mathrm{yr} / \mathrm{M}$ & L temporal & gliosis \\
\hline 14 & 3yr/M & corpus callosum & tuberous sclerosis \\
\hline 15 & $10 \mathrm{yr} / \mathrm{F}$ & $L$ frontal & $\begin{array}{l}\text { Taylor focal cortical dysgenesis; } \\
\text { DNET }\end{array}$ \\
\hline 16 & $10 \mathrm{yr} / \mathrm{M}$ & $R$ frontal & no neocortical lesions \\
\hline 17 & $17 \mathrm{yr} / \mathrm{M}$ & L temporal & DNET \\
\hline 18 & $8 \mathrm{yr} / \mathrm{F}$ & R frontal & focal cortical dysgenesis \\
\hline 19 & $2 \mathrm{yr} / \mathrm{M}$ & L temporal & tuberous sclerosis \\
\hline 20 & $16 \mathrm{yr} / \mathrm{F}$ & $\begin{array}{l}\text { L temporal; } \\
\text { L hippocampus }\end{array}$ & $\begin{array}{l}\text { focal cortical dysgenesis; } \\
\text { mesial gliosis }\end{array}$ \\
\hline 21 & $7 \mathrm{yr} / \mathrm{F}$ & $\begin{array}{l}\mathrm{R} \text { temporal; } \\
\mathrm{R} \text { hippocampus }\end{array}$ & $\begin{array}{l}\text { no lesions; } \\
\text { no lesions }\end{array}$ \\
\hline 22 & $4 \mathrm{yr} / \mathrm{F}$ & L post.temporal & $\begin{array}{l}\text { porencephaly; focal cortical } \\
\text { dysgenesis }\end{array}$ \\
\hline & & L hippocampus & mild mesial gliosis \\
\hline 23 & $23 y r / F$ & R inf.temporal & focal cortical dysgenesis \\
\hline 24 & $13 \mathrm{yr} / \mathrm{F}$ & R temporal & Taylor focal cortical dysgenesis \\
\hline 25 & 3yr/F & $L$ fronta & tuberous sclerosis \\
\hline 26 & $12 \mathrm{yr} / \mathrm{M}$ & $\mathrm{R}$ mesial frontal & tuberous sclerosis \\
\hline 27 & 7yr/F & R parietal & $\begin{array}{l}\text { tuberous sclerosis } \\
\text { (repeat surgery of Case } 8 \text { ) }\end{array}$ \\
\hline 28 & $4 \mathrm{yr} / \mathrm{F}$ & $\mathrm{R}$ parietal & DNET \\
\hline 29 & $10 \mathrm{yr} / \mathrm{F}$ & L frontal & no lesions \\
\hline 30 & $4 \mathrm{yr} / \mathrm{F}$ & L temporal & mesial gliosis \\
\hline 31 & $16 \mathrm{yr} / \mathrm{M}$ & R temporal & mesial gliosis \\
\hline 32 & $4 \mathrm{yr} / \mathrm{M}$ & R temporal & mesial gliosis \\
\hline 33 & $11 \mathrm{yr} / \mathrm{M}$ & $\mathrm{R}$ mesial frontal & DNET \\
\hline 34 & $17 \mathrm{yr} / \mathrm{F}$ & $\mathrm{R}$ mesial frontal & no lesions \\
\hline 35 & $15 y r / M$ & $\begin{array}{l}\mathrm{R} \text { lateral temporal } \\
\mathrm{R} \text { hippocampus }\end{array}$ & $\begin{array}{l}\text { focal cortical dysgenesis; } \\
\text { loss CA1; gliosis }\end{array}$ \\
\hline 36 & 7yr/M & $\begin{array}{l}\mathrm{R} \text { temporal } \\
\mathrm{R} \text { hippocampus }\end{array}$ & $\begin{array}{l}\text { focal cortical dysgenesis } \\
\text { loss CA3 }\end{array}$ \\
\hline 37 & $7 y r / M$ & L post.temp-par & no lesions \\
\hline 38 & $23 \mathrm{mo} / \mathrm{M}$ & $\mathrm{R}$ frontal & $\begin{array}{l}\text { hemimegalencephaly; } \\
\text { cellular atypia }\end{array}$ \\
\hline 39 & $6 y r / F$ & $\mathrm{R}$ frontal & focal cortical dysgenesis \\
\hline 40 & $9 y r / M$ & L frontal & no lesions \\
\hline 41 & $10 \mathrm{yr} / \mathrm{M}$ & $\mathrm{R}$ parietal & focal cortical dysgenesis \\
\hline 42 & $10 \mathrm{yr} / \mathrm{M}$ & L pariet-occip & $\begin{array}{l}\text { focal cortical dysgenesis } \\
\text { (repeat surgery of Case } 41 \text { ) }\end{array}$ \\
\hline 43 & $2 \mathrm{yr} / \mathrm{M}$ & $\begin{array}{l}\mathrm{R} \text { temporal; } \\
\mathrm{R} \text { hippocampus, } \\
\text { amyg }\end{array}$ & tuberous sclerosis \\
\hline 44 & $3 y r / F$ & $\begin{array}{l}\text { L frontal } \\
L \text { temporal } \\
L \text { parietal } \\
\text { L hippocampus }\end{array}$ & $\begin{array}{l}\text { focal cortical dysgenesis } \\
\text { focal cortical dysgenesis } \\
\text { focal cortical dysgenesis } \\
\text { neuronal loss CA1, CA3 }\end{array}$ \\
\hline 45 & $16 y r / M$ & $\begin{array}{l}\text { L temporal } \\
\text { L hippocampus }\end{array}$ & $\begin{array}{l}\text { mild focal cortical dysgenesis } \\
\text { neuronal loss CA3; gliosis }\end{array}$ \\
\hline
\end{tabular}

DNET=dysembryoplastic neuroepithelial tumour; temp=temporal; pariet=parietal; occip=occipital; amyg=amygdala; $y r=y e a r$ old; $\mathrm{mo}=$ month old; R=right; $\mathrm{L}=$ left; $\mathrm{F}=$ female; $\mathrm{M}=$ male 
Ki-67 (MIB-1) proliferating cell nuclear antigen and histochemical stains for periodic acid-Schiff (PAS) reaction; acridine orange (AO) fluorochrome; Bielschowsky silver impregnation.

For electron microscopy (EM), separate grey and white matter samples were taken near the epileptic focus. The rationale for performing EM in these cases was to determine whether upregulated $\alpha$-B-crystallin has an ultrastructural correlate as a metabolic storage product or as granular or filamentous deposits in the cytoplasm.

Controls. Surgically resected or biopsied normal brain tissue is not available for controls, and biopsies of cerebral lesions such as encephalitis or tumours cannot serve as controls because these conditions also may upregulate $\alpha$-B-crystallin, thus losing the specificity for epileptogenic brain. We therefore used normal paediatric cerebral cortex and underlying white matter from autopsies of children who had died of non-neurological causes and who did not have neurological disease or epilepsy during life. The six cases, from 3 months to 14 years-of-age, had autopsy and fixation of the tissue within 24 hours after death, avoiding prolonged postmortem autolytic changes; the fixation of the brain tissue was one to two weeks before sectioning. Routine neuropathological examination of these brains revealed no gross or microscopic lesions. The control of a-B-crystallin of the autopsy brain tissue were not only the two epilepsy cases of this study but also a brain that had prolonged ischaemia before death and showed upregulation throughout the cerebrum and brainstem and a spinal cord with radiation necrosis. The time to fixation between out postmortem epilepsy cases and the controls was less than 12 hours and was not considered significant. The $\alpha$-B-crystallin molecule is very resistant to postmortem autolysis and we have demonstrated it still strongly expressed in brain at more than 72 hours at autopsy in other nonepileptic conditions.

Autopsy epilepsy cases. Postmortem examination of the brains of two children, a 5-year-old girl with global developmental delay and epilepsy, and an 11-year-old girl with genetically confirmed Rett syndrome, both of whom died with chronic, pharmacologically refractory epilepsy, also were examined, including deep structures and brainstem, in addition to bilateral regions of cerebral cortex and hippocampus. Patients had been followed in clinic and had serial EEG and MRI studies during life, but did not undergo the extensive preoperative EEG monitoring that the surgical cases received because neither of these two patients fulfilled clinical criteria for surgical treatment of their epilepsy. The epileptic foci were, therefore, not as precisely localized as in the surgical cases, but the serial scalp EEGs provided a general guide to the most epileptogenic regions of the cortex.

Postmortem normal fetal and neonatal brains. Normal fetal and neonatal brains of various gestational and postnatal conceptional ages ranging from 10 to 41 weeks also were examined at autopsy. Twenty brains were selected of fetuses and neonates who had died of non-neurological causes or were fetuses terminated electively at midgestation. Gestational ages were: four cases at 10-16 weeks, nine at 17 to 22 weeks, three at 23-34 weeks and four at 35-41 weeks. At autopsy, none of the brains exhibited major lesions. Microscopic germinal matrix or subarachnoid fresh haemorrhages were not exclusion criteria. Microscopic sections were prepared as with the surgical cases.

\section{RESULTS}

Microscopic diagnoses were: 9 no histological lesions demonstrated; 17 focal neocortical dysplasia; 1 margin of porencephalic cyst with polymicrogyria; 9 tuberous sclerosis; 1 hemimegalencephaly; 5 DNET; 1 subacute viral encephalitis with perivascular lymphocytic infiltrates (not Rasmussen encephalitis). Many of the hippocampi exhibited classical chronic gliosis ("mesial temporal sclerosis") and neuronal loss in CA3 and CA1 sectors of Ammon's horn; one case showed an unusual selective CA2 neuronal loss.

Focal cortical dysplasias varied in architecture from persistent fetal radial columnar, rather than laminar, architecture, to less organized nonlaminated organization of the cortex with many displaced and disoriented neurons, often associated with heterotopic neurons in the subcortical white matter, singly or in small clusters. Satellitosis was prominent in cortex and glial cells adherent to heterotopic neurons in white matter. Two of the focal cortical dysplasias were of the Taylor type with balloon cells.

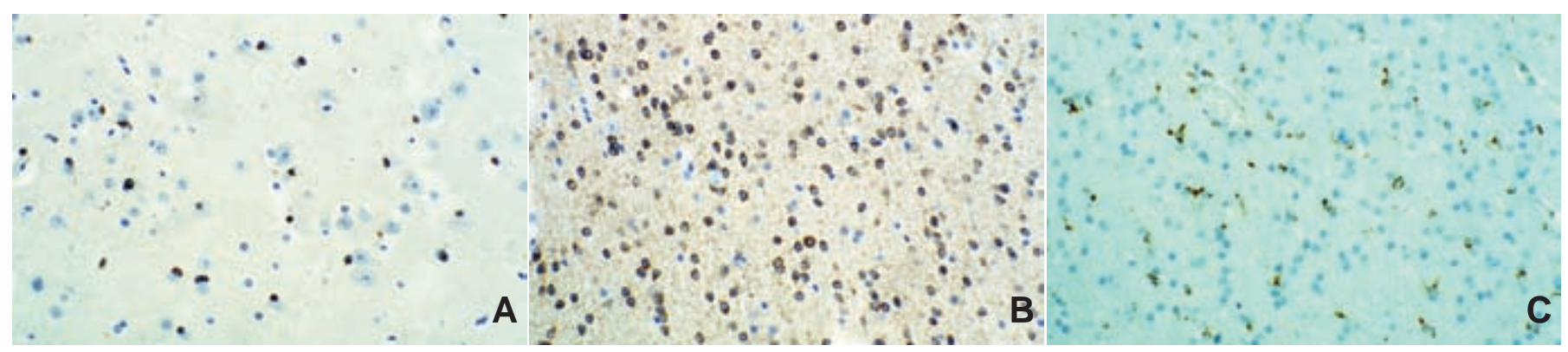

Figure 1: 15-year-old boy; resection of R frontal epileptic focus. Histopathology showed no cortical dysplasia, inflammation, infarcts or other lesions. (A) cortical grey matter shows intense reactivity of satellite glial cells, but not neurons; (B) subcortical white matter shows strong reactivity in more than $90 \%$ of glial cells, including satellite cells adherent to a heterotopic neuron; $(C)$ scattered microglial cells are demonstrated, but not an intense microglial activation. $(A, B) \alpha-B$-crystallin, X400; (C) CD-68, X250. 


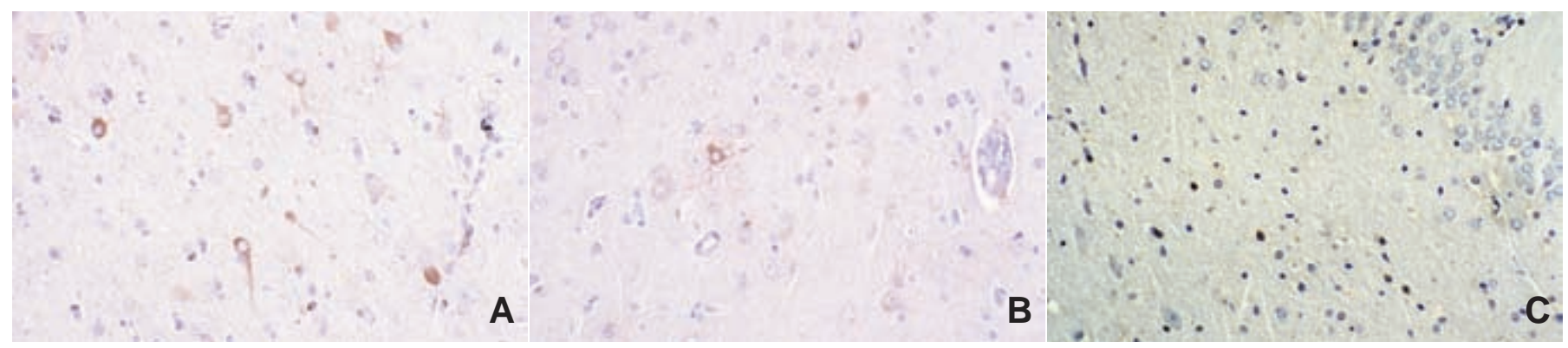

Figure 2: 15-year-old boy with R temporal resection, which showed neuronal loss from CA1 sector of Ammon's horn, hippocampal gliosis and focal dysplasia of temporal neocortex. (A) Within the neocortex, both neurons and some satellite glial cells are strongly reactive, but some reactive neurons have adherent satellite glial cells that are nonreactive; $(B)$ Some glial cells in the grey-white matter junction of the cortex not only show reactivity in their perinuclear cystoplasm, but also in their radiating processes; (C) Neurons of the dentate gyrus are nonreactivity and only a few scattered glial cells exhibit reactivity. (A-C) $\alpha$-B-crystallin, X400.

One of these was in cortex adjacent to a lesion of DNET. In most of the cases of focal cortical dysplasia, an excessive number of scattered heterotopic neurons were demonstrated in the subcortical white matter. Heterotopic neuronal clusters were seen in white matter in tuberous sclerosis.

Epileptic foci. In every surgical epileptic case, $\alpha$-B-crystallin was upregulated at or near to the epileptic focus that had been identified by preoperative EEG monitoring and intraoperative ECoG. The distribution involved nearly all glial cells of the white matter underlying epileptogenic cortex, both astrocytes and oligodendrocytes, including cases in which there was no demonstrable histological lesion (Figure 1). The reactivity in glial cells was mainly in the cytoplasm of cell bodies, but multiple astrocytic processes radiated from the somata of some cells with considerable detail. Similar $\alpha$-B-crystallin reactivity was seen in glial cells of white matter, both astrocytes and oligodendrocytes, associated with focal cortical dysgenesis. Heterotopic neurons in the white matter also had strongly reactive satellite glial cells. In three cases without tuberous sclerosis and all cases with this genetic disease, reactivity was demonstrated in neurons of the neocortex and especially in pyramidal neurons of Ammon's horn, but paradoxically the satellite glial cells adherent to these neuronal soma often failed to express $\alpha$-B-crystallin (Figure 2). These reactive neurons expressed $\alpha$-B-crystallin in their somatic cytoplasm as a diffuse, amorphous reaction product, not granular or filamentous, and reactivity also was seen in their proximal neurites. Though the neuronal reactivity was most frequent in Ammon's horn, in most hippocampal resections only satellite glial cells were reactive.

In the majority of cases, all areas of the resected brain tissue showed a similar, diffuse overexpression of glial $\alpha$-B-crystallin but, in 6 of the 43 surgical cases, a qualitative gradient was demonstrated, with strong reactivity at or near to the epileptic focus as identified by EEG and ECoG recordings, but diminishing intensity of reactivity and fewer cells reactive distal to the focus, until no further reactivity was seen at $2.5-3 \mathrm{~cm}$ away from the focus (Figure 3), but the transitional zone between reactive and nonreactive cells was gradual rather than abrupt. In some cases with extensive resections of one hemisphere, strong reactivity was seen in regions where active epileptic foci were

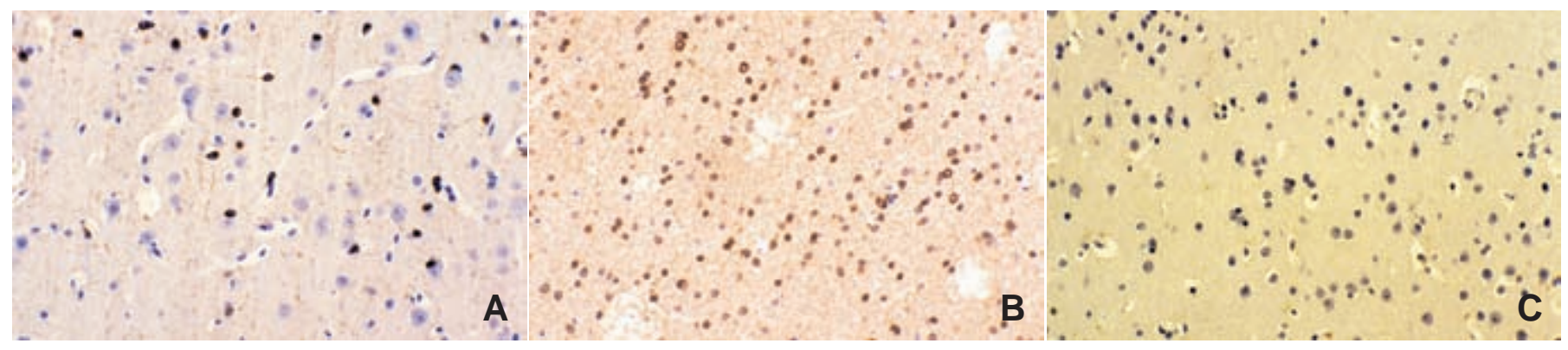

Figure 3: Resection of a parasagittal parieto-occipital epileptic focus in a seven-year-old girl, who has had epilepsy since a year of age, associated with normal development. Focal dysplasia was seen histologically. (A) The cortical grey matter shows strongly reactive satellite cells, but nonreactive neurons; $(B)$ The white matter near to the cortex has uniformly intensely reactive glial cells; $(C)$ The grey-white matter junction about $2.5 \mathrm{~cm}$ distal to the epileptic focus with reactive cells seen in $(A)$ and $(B)$ shows no reactivity in glial cells, heterotopic neurons or satellite cells. Such a gradient of diminishing and then absence of $\alpha$-B-crystallin expression was seen in several cases. $\alpha$-B-crystallin. (A-C) X400. 
demonstrated by EEG, and no reactivity was demonstrated in other regions where no epileptiform activity was seen despite the presence of lesions such as focal cortical dysgenesis of mesial temporal sclerosis (Figure 4). None of the autopsy controls showed $\alpha$-B-crystallin expression in white or grey matter.

The intensity of reactivity within cells varied between cases, but at least weak reactivity was seen in all. Balloon cells in the Taylor-type focal cortical dysplasia and in the large aberrant balloon cells in tuberous sclerosis, were uniformly intensely reactive and normal sized glial cells in tuberous sclerosis also were intensely marked (Figure 5). Some of the marked cells were clearly more neuronal than glial in morphology and by other immunocytochemical markers. Reactivity in tuberous sclerosis also was strong in areas that were not frank cortical tubers and in which no atypical giant cells were found. Reactivity of a variety of cellular types in an epileptic resection of hemimegalencephaly was similar.

Even in cases showing no microscopic lesions, as well as in those showing focal cortical dysplasia, the intensity of reactivity became weaker or expression disappeared entirely about $2.5 \mathrm{~cm}$ away from the epileptic focus. In the two postmortem cases, reactivity also was seen only in the region of epileptic foci and not in other regions of cerebral cortex, deep grey or white matter of the telencephalon, diencephalon, brainstem or cerebellum.

No correlation with microglial activation was found (Figure 1C). Whereas CD-68 reactive microglial cells were increased in a few cases, $\alpha$-B-crystallin was not especially intense and the majority of cases showed no microglial activation. Inflammatory

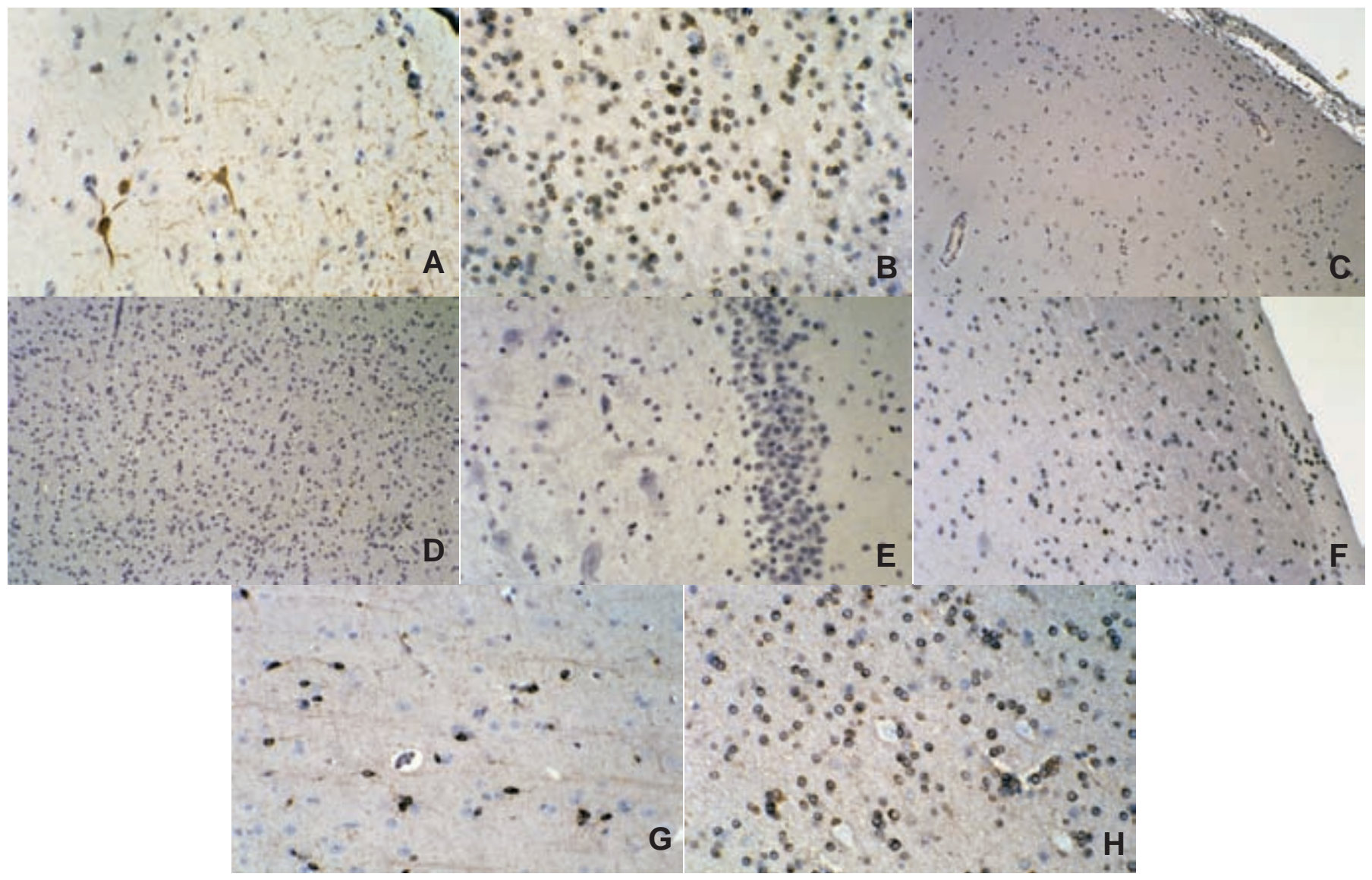

Figure 4: Extensive left hemispheric resection of a three-year-old girl with refractory partial epilepsy for the past year and MRI evidence of widespread focal cortical dysplasia in that hemisphere or Rasmussen encephalitis. Neuropathological examination confirmed multifocal neocortical dysplasia of non-Taylor type but no inflammation or evidence of encephalitis, vasculitis, infarction or neoplasia. The hippocampus showed mesial temporal sclerosis with extensive neuronal loss in CA1 and CA3 sectors of Ammon's horn, with preservation of CA2 and CA4. (A) frontal cortex; (B) frontal white matter; $(C)$ temporal neocortex $(D)$ temporal white matter; $(E)$ hippocampus, dentate gyrus; $(F)$ CA3 sector of Ammon's horn and alveus; $(G)$ parietal cortex; (H) parietal white matter. There is strong expression of $\alpha$-B-crystallin in some neurons as well as in satellite glial cells of the frontal cortex (A) as well as in glial cells only in the parietal cortex $(G)$, and in more than $80 \%$ of glial cells in the subcortical white matter of both regions $(B, H)$. The temporal neocortex, white matter and hippocampus exhibit no reactivity in any cells. All sections were incubated together, providing internal control as well as the simultaneously incubated control of another case. The reactivities in the tissue sections correlate well with the neurophysiological findings: preoperative EEG monitoring and intraoperative electrocorticography showed actively discharging epileptic foci in frontal and parietal lobes, but not arising in the temporal lobe, though occasionally showing secondary temporal spread. $\alpha$-B-crystallin, $(A, B, E, F, G, H) X 250 ;(C, D) X 100$. 


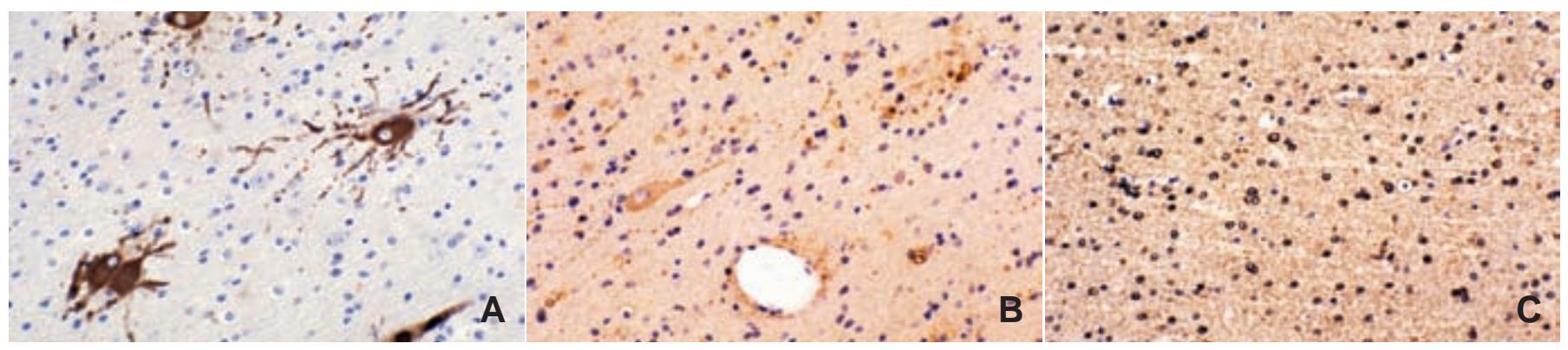

Figure 5: Three cases of tuberous sclerosis: A) 2-year-old girl; white matter deep to epileptic focus in left superior temporal gyrus. Several balloon cells are intensely immunoreactive, including their coarse radiating processes, but other glial cells and neurons in the vicinity are mostly nonreactive, with only scattered reactive cells. B) 31/2-year-old girl with continuous epileptiform activity generated in a left frontal cortical tuber. The white matter $2 \mathrm{~cm}$ away from the tuber shows strongly reactive large and small cells and many nonreactive small cells. The large heterotopic neuron seen at the left is strongly reactive. C). 12-year-old boy; this mesial frontal lobe tissue is part of a cortical dysplasia, but is not a classical tuber. Reactivity is seen in nearly all cells. No balloon cells are demonstrated in this field. $\alpha$-B-crystallin, X400.

cells, such as lymphocytes and tissue macrophages, were absent, except for a few lymphocytes in the meninges in sites of previous subdural electrodes. Correlation with either chronic or recent gliosis also could not be established, including subpial gliosis or mesial temporal gliosis involving the hippocampus. Regions of focal neuronal loss in Ammon's horn and the dentate gyrus also did not predict a more intense immunoreactivity of $\alpha$-Bcrystallin. The presence of hippocampal gliosis and its extent could not be correlated with the $\alpha$-B-crystallin reactivity within the hippocampus.

Electron microscopy of neurons and glial cells showed no increase in fibrillary structures, storage material or other ultrastructural alterations in organelles. Abnormal cells in tuberous sclerosis and balloon cells in Taylor focal cortical dysgenesis exhibited an abundance of intermediate filaments.

Postmortem brains in epilepsy. The regions of the cerebral cortex that had been identified as epileptogenic in life showed reactivity of $\alpha$-B-crystallin in glial cells of both the grey matter as satellite cells adherent to neurons and in the white matter underlying these regions. Nonepileptic areas were nonreactive, and reactivity was not seen in subcortical structures, including the thalamus, basal ganglia, brainstem and cerebellum.

Ontogenesis. None of the fetal or neonatal brains examined showed expression of $\alpha$-B-crystallin in any parenchymal cells at any gestational age (Figure 6). In brains of 30 weeks gestation or more, we found weak reactivity in astrocytes of the subpial granular glial layer of Brun, but not in astrocytes of the cortex or white matter. Fetal brains as early as 30 weeks gestation are capable of expressing upregulated $\alpha$-B-crystallin in conditions of chronic and severe fetal ischaemia with intrauterine growth retardation, but these data are not included in the present study.

Tuberous sclerosis, hemimegalencephaly and Taylor-type focal dysgenesis with balloon cells. We found a uniformly intense upregulation of $\alpha$-B-crystallin in the large atypical cells in our five cases of tuberous sclerosis, one case of hemimegalencephaly and in the balloon cells in two cases of Taylor-type focal cerebral dysgenesis. Not only were the globular soma of these cells strongly reactive, but their coarse radiating processes also were well demonstrated. In tuberous sclerosis, there was overexpression of $\alpha$-B-crystallin in most glial cells throughout the subcortical white matter, even in those that were not morphologically abnormal or enlarged. Whether the $\alpha$-B-crystallin in these cells was the natural or a mutated form was not determined.

Dysembryoplastic neuroepithelial tumours (DNET). Strong reactivity was found in the four cases of DNET, in both neurons and glia within the septa between microcysts of mucinous secretions. Within these septa were neurons reactive for NeuN and synaptophysin and also astrocytes reactive with GFAP antibody; these astrocytes were the cells that exhibited $\alpha$ B-crystallin. The DNET lesions were the site of epileptiform activity recorded by preoperative EEG and by intraoperative ECoG. In one patient, a Taylor-type focal cortical dysplasia with

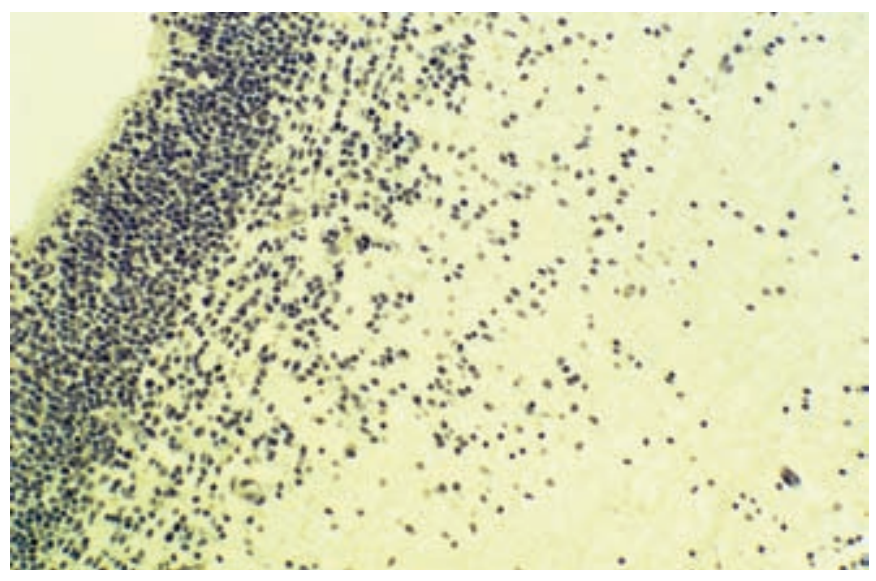

Figure 6: Cortical plate and subcortical white matter in a normal early human fetus of 10 weeks gestation. No expression of $\alpha$-B-crystallin is demonstrated at this or any other gestational age except weakly in subpial glial cells of Brun in fetuses older than 30 weeks (not shown). $\alpha$ B-crystallin. X400. 
megalocytic neurons and balloon cells was found in the adjacent neocortex. The $\alpha$-B-crystallin reactivity was seen not only within the DNET lesion itself, including in cells of the septa between mucinous microcysts, but also in the region surrounding, including adjacent focal cortical dysplasia and in the white matter of normal cortex at the margins of the resection.

\section{Discussion}

Heat shock proteins and $\boldsymbol{\alpha}$-B-crystallin. Heat-shock proteins are molecular chaperones that are thought to protect proteins from damage induced by factors such as free radicals, heat, ischaemia, irradiation, toxins and neoplasia, allowing denatured proteins to adopt their native configuration ${ }^{8}$, but this interpretation has recently been questioned and alternatively suggested that they reflect stress rather than protection, particularly in epilepsy ${ }^{7}$.

The protein $\alpha$-B-crystallin (molecular weight $34 \mathrm{kDa}$ ) is slightly larger than, but has a molecular structure closely related to, heat shock protein (HSP)-27 (27 kDa). The "A" and "B" of the alpha crystallins refer to "acidic" or "basic". $\alpha$-crystallins are one of two genetic families of "chaperone proteins", the other being $\beta-\gamma$-crystallins ${ }^{6}$. A chaperone may be defined as "any of a diverse group of proteins that oversee the correct intracellular folding and assembly of polypeptides without being components of the final structure" $"$. These chaperone crystallins are ancient in evolution and are demonstrated in some bacteria, simple worms and in mitochondria. They exist in both the nucleus and cytoplasm. Experimentally, crystallin genes may be induced in $E$. coli bacteria $^{10}$ and transgenically in the roundworm $C$. elegans ${ }^{11}$.

Heat-shock proteins are involved in protein folding, assembly and transport and the regulation of cell growth and apoptosis ${ }^{12}$. The functions of $\alpha$-B-crystallin in this regard are suggested in the medical dictionary definition of a chaperone protein as proteins "...that play a role in the process of protein folding and translocation by binding to newly synthesized protein chains and preventing interactions with other proteins that might interfere with the intended pathway"13. Chaperone proteins possess the ability to prevent target protein interactions and aggregation of misfolded proteins ${ }^{14}$; they are, thereby, protective molecules during times of stress or shock. The domain of $\alpha$-B-crystallin inhibits the aggregation of tubulin and other microtubuleassociated proteins in particular ${ }^{15-17}$. Decreased $\alpha$-B-crystallin occurs with muscular atrophy and is associated with decreased amounts of tubulin ${ }^{18}$. The regulation of chaperone activity by $\alpha$ $\mathrm{B}$-crystallin is related to its phosphorylation, which enables it to act as a protector of the cytoskeleton ${ }^{19-21}$. It is present in amyloid fibrils, where its hydrophilic C-terminus protrudes from the fibrillar core ${ }^{14}$. Gamma irradiation results in huge aggregates and inactivation of $\alpha$-B-crystallin ${ }^{22}$. There is an expanding biochemical literature on the various mutations in human $\alpha$-Bcrystallin, particularly truncation of the C-terminus, and mutation in its gene. Mutant forms of the molecule chiefly occur in genetic diseases.

Alpha-B-crystallin as a tissue marker of epileptic foci. This study demonstrates that $\alpha$-B-crystallin is useful in identifying epileptic foci and is not diffusely upregulated throughout the brains of epileptic children, if other "stresses" known to upregulate this protein are excluded. Reactivity is mainly in glial cells, including satellite glia adherent to neurons, but also involves neurons in some cases. It is seen in both neocortical grey matter and subcortical white matter, and in the hippocampus and amygdala. As distance increases from an epileptic focus identified electrophysiologically, the reactivity of $\alpha$-B-crystallin diminishes and disappears in some cases. The presence of structural lesions appears to be of little importance; $\alpha$-B-crystallin expression may be equally intense in tissue that is histologically normal and shows normal immunoreactivities with standard markers. Gliosis and microglial activation also are not predictive features. Thus $\alpha$-B-crystallin is a marker of epileptic foci and enables the mapping of the extent of the focus and its margins. Our two postmortem brains were important because they enabled examination of regions not accessible in surgical resections. These data further supported the gradient concept that expression of $\alpha$-B-crystallin is indeed a local phenomenon not generalized throughout the brain. Such data in epileptic resections might help determine whether an epileptic focus was completely excised and be correlated with postoperative EEG findings and subsequent clinical course. In a minority of our cases, $\alpha$-B-crystallin was expressed in neurons in epileptic foci of the hippocampus, but in the majority of cases its expression was limited to glial cells of white matter and satellite glia adherent to neuronal soma in grey matter. Satellitosis is a common, nonspecific phenomenon in many encephalopathies.

The significance of neuronal expression remains uncertain. It is unlikely that "stress" from the physical trauma of cerebral resection induces $\alpha$-B-crystallin expression because the margins of the resection were generally the least reactive parts of the biopsy. The significance of $\alpha$-B-crystallin reactivity in neurons in a few cases, mostly in pyramidal neurons of Ammon's horn in the hippocampus, remains uncertain at this time. These cases showed no other distinctive distinguishing features, either clinically or pathologically. The upregulation of this protein is not a reversion to a normal developmental stage in ontogenesis, as shown by our fetal studies (Figure 6).

Whether a single seizure can upregulate $\alpha$-B-crystallin or only recurrent seizures effects this overexpression cannot be known in human tissue because surgery is not performed for a first seizure. This question might be approached in future in animal studies, however.

In DNETs, $\alpha$-B-crystallin upregulation within the septa of neural tissue between mucinous microcysts ${ }^{23-25}$ is consistent with electrophysiological data that epileptogenesis arises within the lesion itself, not just in surrounding dysplastic cortex ${ }^{26}$.

Small heat shock proteins, including $\alpha$-B-crystallin, are developmentally regulated ${ }^{27}$. We were unable to demonstrate the immunocytochemical expression of $\alpha$-B-crystallin as a normal transient stage at any gestational age, including in neuroepithelial cells retaining proliferative potential, lining the ventricles before midgestation. Expression is reported in differentiating porcine neural stem cells, however ${ }^{28}$. Though this is a study of paediatric epilepsy, we also have examined $\alpha$-Bcrystallin in several adult resections for epilepsy (one included in this series) and expression appears similar to children.

No correlation could be established between $\alpha$-B-crystallin upregulation and focal gliosis, as shown by either vimentin for recent astrocytic proliferation or GFAP for more chronic gliosis. Sequestration of $\alpha$-B-crystallin is found in the Rosenthal fibres 
of Alexander disease, astrocytic processes greatly distended by proliferated GFAP filaments ${ }^{29}$. The absence of correlation in epileptic children of $\alpha$-B-crystallin with microglial activation, as shown by CD-68, is of particular interest because neurons are not merely passive targets of microglia as previously thought, but rather control microglial activity with "on" and "off signals mediated by purines, chemokines and glutamate ${ }^{30}$. Despite this evidence, epileptic neurons do not appear to induce microglial activation. Inflammatory lymphocytes were not seen in the brains here studied, except in one case of encephalitis and in the meninges limited to sites of previous subdural electrode placement. The expression of $\alpha$-B-crystallin in those regions of electrodes was no different than elsewhere and we do not conclude that the temporary presence of subdural electrodes prior to surgery contributed to its expression. The stress of the surgery itself also was not a factor, as shown in the cases in which a gradient exhibited stronger reactivity in the centre of the tissue and weak to absent reactivity near to the cut surfaces of the tissue.

Specificity and quantitation of $\alpha$-B-crystallin. As noted above, heat shock protein in general, including $\alpha$-B-crystallin, are nonspecific in the sense that they may be upregulated by a variety of "stresses". The specificity for epileptic foci, as one more factor in the list of stresses, must be inferred by process of elimination. Many of the conditions can easily be excluded by clinical or pathological criteria, such as malignant neoplasms, neurodegenerative diseases such as Alzheimer and Parkinson diseases, radiation-induced encephalopathy, severe ischaemic encephalopathy, "ventilator brain", infections of the CNS and protracted fever. By these exclusions, unless there is another yet unknown trigger of upregulation, epilepsy is the only remaining evident factor and $\alpha$-B-crystallin thus becomes a reliable and specific marker of epileptic foci.

One of the weaknesses of our present study is that the results are not quantitative, but rather based upon visual identification of immunoreactivity in tissue sections. More precise quantitation could be designed in a study using western blot analysis, for example, but this would be a different study than we have here performed and is considered for future extension of our present data. We attempted to reduce as many variabilities as possible, such as fixation time of the tissues, thickness of sections, uniform techniques of applying the antibody of standard concentration and incubation period, and we believe we have achieved the most reliable and reproducible results that can be demonstrated using immunocytochemistry as a qualitative tissue marker. The gradients seen in six of the cases were based on intensity of qualitative reactivity, in comparison with other regions of the tissue of the same brain, and the ratio of reactive and nonreactive glial cells. Gradients require additional confirmation in future using more quantitative methods.

Future Directions. The most compelling correlation of this initial study is with long-term clinical outcome, in particular to determine whether $\alpha$-B-crystallin in cases showing a gradient in which the margins of the resected tissue are free of reactive cells, can serve as a reliable predictor of recurrence of epilepsy. We do not presently have sufficient data over a long enough period from which to derive conclusions, but this study is in progress and preliminary results are promising; the full results will be reported later as a separate publication because it really constitutes an entirely different study than the present data. It will be important in future to also determine whether the upregulated $\alpha$-Bcrystallin in chronic epilepsy is the normal or is a mutated molecule as in some neurodegenerative diseases. Quantitation will be another goal of further studies of $\alpha$-B-crystallin.

\section{ACKNOWLEDGEMENTS}

The authors thank Drs. Jeffrey T. Joseph and James R. Wright, Jr., Department of Pathology at the University of Calgary for their thoughtful comments. The general autopsies of cases in this study were performed by Drs. Alfredo Pinto-Rojas and James Wright at Alberta Children's Hospital. Technical assistance was provided by Gaston Guenette, Teresa Ortez and Patricia McGinnis of the Alberta Children's Hospital Histopathology Laboratory, by Tracey Lenek and her staff at the Calgary Laboratory Services Immunopathology Laboratory and by Elaine Yung and Weyman Chan at the Electron Microscopy Laboratory. Neurosurgical resections were performed by Dr. Walter Hader. Preoperative and intraoperative clinical neurophysiology was performed by Drs. Ismail Mohamed or Lori Hamiwka. Dr. Elaine Wirrell participated in the management of some patients.

This study was supported by the Department of Pathology and Laboratory Medicine, University of Calgary Faculty of Medicine and Alberta Children's Hospital and by Calgary Laboratory Services and Calgary Health Region, Province of Alberta.

\section{REFERENCES}

1. Schramm J. Temporal lobe epilepsy surgery and the quest for optimal extent of resection: a review. Epilepsia. 2008;49: 1296-307.

2. Aull-Watschinger S, Pataraia E, Czech T, Baumgartner C. Outcome predictors for surgical treatment of temporal lobe epilepsy with hippocampal sclerosis. Epilepsia. 2008;49:1308-16.

3. Uijl SG, Leijten FSS, Arends JBAM, Parra J, van Huffelen AC, Moons KGM. Prognosis after temporal lobe epilepsy surgery: the value of combining predictors. Epilepsia. 2008;49:1317-23.

4. Kappe G, Franck E, Verschuure P, Boelens WC, Leunissen JA, de Jong WW. The human genome encodes $10 \alpha$-crystallin-related small heat shock proteins: HspB1-10. Cell Stress Chaperones. 2003;8:53-61.

5. Koteiche HA, McHaourab HS. Mechanism of a hereditary cataract phenotype. Mutations in alpha-crystallin activate substrate binding. J Biol Chem. 2006;281:14273-9.

6. Andley UP. Crystallins in the eye: function and pathology. Progr Retin Eye Res. 2007;26:78-98.

7. Yang T, Hsu C, Liao W, Chuang JS. Heat shock protein 70 expression in epilepsy suggests stress rather than protection. Acta Neuropathol. 2008;115:219-30.

8. Ferns G, Shams S, Shafi S. Heat shock protein 27: its potential role in vascular disease. Int J Exp Pathol. 2006;87:253-74.

9. Dorland's Illustrated Medical Dictionary. 30th ed. Philadelphia: WB Saunders; 2003. p. 341.

10. Takeuchi S, Mandai Y, Otsu A, Shirakawa T, Masuda K, Chinami M. Differences in properties between human $\alpha$-A- and $\alpha$-Bcrystallin proteins expressed in Escherichia coli cells in response to cold and extreme pH. Biochem J. 2003;375(Pt 2):471-5.

11. Link CD, Taft A, Kapulkin V, Duke K, Kim S, Fei Q, et al. Gene expression analysis in a transgenic Caenorhabditis elegans Alzheimer's disease model. Neurobiol Aging. 2003;24:397-413.

12. Adly MA, Assaf A, Hussein MR. Expression of the head shock protein-27 in the adult human scalp skin and hair follicle: hair cycle-dependent changes. J Am Acad Dermatol. 2006;54:811-17.

13. Melloni's Illustrated Medical Dictionary. 4th ed. London, UK: Parthenon Publishing Group; 2002. p. 120. 
14. Meehan S, Knowles TP, Baldwin AJ, Smith JF, Squires AM, Clements $\mathrm{P}$, et al. Characterisation of amyloid fibril formation by small heat-shock chaperone proteins human alpha-A-, alpha-Band R120G alpha-B-crystallins. J Mol Biol. 2007;372:470-84.

15. Fujita Y, Ohto E, Katayama E, Atomi Y. $\alpha$-B-crystallin-coated MAP microtubule resists nocodazole and calcium-induced disassembly. J Cell Sci. 2004:117:1719-26.

16. Aquilina JA, Benesch JL, Ding LL, Yaron O, Horwitz J, Robinson $\mathrm{CV}$. Phosphorylation of $\alpha$-B-crystallin alters chaperone function through loss of dimeric substructure. J Biol Chem. 2004;279: 28675-80.

17. Ohto-Fujita E, Fujita Y, Atomi Y. Analysis of the alphaB-crystallin domain responsible for inhibiting tubulin aggregation. Cell Stress Chaperones. 2007;12:163-71.

18. Sakurai T, Fujita T, Ohto E, Oguro A, Atomi Y. The decrease of the cytoskeleton tubulin follows the decrease of the associating molecular chaperone $\alpha$-B-crystallin in unloaded soleus muscle atrophy without stretch. FASEB J. 2005;19:1199-201.

19. den Engelsman J, Gerrits D, de Jong WW, Robbins J, Kato K, Boelens WC. Nuclear import of $\{$ alpha\}B-crystallin is phosphorylation-dependent and hampered by hyperphosphorylation of the myopathy-related mutant R120G. J Biol Chem. 2005;280:37139-48.

20. Launay N, Goudeau B, Kato K, Vicart P, Lilienbaum A. Cell signaling to $\alpha$-B-crystallin following stresses of the cytoskeleton. Exp Cell Res. 2006;312:3570-84.

21. Ecroyd H, Meehan S, Horwitz J, Aquilina JA, Benesch JL, Robinson $\mathrm{CV}$, et al. Mimicking phosphorylation of $\alpha$-Bcrystallin affects its chaperone activity. Biochem J. 2007;401:129-41.
22. Fujii N, Nakamura T, Sadakane Y, Saito T, Fujii N. Differential susceptibility of alpha-A- and alpha-B-crystallin to gamma-ray irradiation. Biochim Biophys Acta. 2007;1774:345-50.

23. Hirose T, Scheithauer BW, Lopes MB, VanderBerg SR. Dysembryoplastic neuroepithelial tumor (DNT): an immunohistochemical and ultrastructural study. J Neuropathol Exp Neurol. 1994;53:184-95.

24. Prayson RA, Morris HH, Estes MI, Comair YG. Dysembryoplastic neuroepithelial tumor: a clinicopathological and immunohistochemical study of 11 tumors including MIB1 immunoreactivity. Clin Neuropathol. 1996;15:47-53.

25. Honavar M, Janota I, Polkey CE. Histological heterogeneity of dysembryoplastic neuroepithelial tumors: identification and differential diagnosis in a series of 74 cases. Histopathology. 1999;34:342-56.

26. Lee M-C, Kang JY, Seol MB, Kim HS, Woo JY, Lee JS, et al. Clinical features and epileptogenesis of dysembryoplastic neuroepithelial tumor. Child's Nerv Syst. 2006;22:1611-18.

27. Ha Y, Kim TS, Yoon DH, Cho YE, Huh SG, Lee KC. Reinduced expression of developmental proteins (nestin, small heat shock protein) in and around cerebral arteriovenous malformations. Clin Neuropathol. 2003;22:252-61.

28. Skalnikova H, Halada P, Vodicka P, Motlik J, Rehulka P, Horning O, et al. A proteomic approach to studying the differentiation of neural stem cells. Proteomics. 2007;7:1825-38.

29. Quinlan RA, Brenner M, Goldman JE, Messing A. GFAP and its role in Alexander disease. Exp Cell Res. 2007;313:2077-87.

30. Biber K, Neumann H, Inoue K, Boddeke HWGM. Neuronal 'on' and 'off' signals control microglia. Trends Neurosci. 2007; 30:596-602. 